\title{
Papers
}

\section{Soya food intake and risk of endometrial cancer among Chinese women in Shanghai: population based case-control study}

\author{
Wang Hong Xu, Wei Zheng, Yong Bing Xiang, Zhi Xian Ruan, Jia Rong Cheng, Qi Dai, Yu Tang Gao, Xiao Ou Shu
}

\begin{abstract}
Objective To evaluate the association of intake of soya food, a rich source of phytoestrogens, with the risk of endometrial cancer.

Design Population based case-control study, with detailed information on usual soya food intake over the past five years collected by face to face interview using a food frequency questionnaire.

Setting Urban Shanghai, China.

Participants 832 incident cases of endometrial cancer in women aged of 30 to 69 years diagnosed during 1997-2001 and identified from the Shanghai Cancer Registry; 846 control women frequency matched to cases on age and randomly selected from the Shanghai Residential Registry.

Main outcome measures Odds ratios for risk of endometrial cancer in women with different intakes of soya foods.

Results Regular consumption of soya foods, measured as amount of either soya protein or soya isoflavones, was inversely associated with the risk of endometrial cancer. Compared with women with the lowest quarter of intake, the adjusted odds ratio of endometrial cancer was reduced from 0.93 to 0.85 and 0.67 with increasing quarter of soya protein intake $(\mathrm{P}$ for trend 0.01). A similar inverse association was observed for soya isoflavones and soya fibre intake. The inverse association seemed to be more pronounced among women with high body mass index and waist:hip ratio.

Conclusion Regular intake of soya foods is associated with a reduced risk of endometrial cancer.
\end{abstract}

\section{Introduction}

Soya foods are a rich source of isoflavones such as genistein and diadzein, a major group of phytoestrogens that have both weak oestrogenic and anti-oestrogenic activities. ${ }^{12}$ Phytoestrogens have been shown to alter endogenous oestrogen concentrations by binding competitively to oestrogen receptors, ${ }^{3}$ inhibiting important steroid biosynthetic enzymes, ${ }^{4}$ increasing the clearance of steroids from the circulation, ${ }^{5}$ and stimulating the production of sex hormone binding globulin. ${ }^{6}$ Soya foods also contain high amounts of dietary fibre, which has been shown to lower serum oestrogen by decreasing the concentration of intestinal $\beta$ glucuronidase, increasing elimination of oestrogen through the faecal route, and reducing intestinal reabsorption. ${ }^{78}$

As endogenous oestrogens have a central role in the aetiology of endometrial cancer, ${ }^{9}$ factors that alter endogenous oestrogen concentrations, such as phytoestrogens and fibre, may be related to the risk of the disease. Circumstantial supporting evidence is available showing that Asian women have a lower incidence of endometrial cancer and eat more soya food than their Western counterparts. ${ }^{10}$ Analytical epidemiological studies on intake of soya foods and risk of endometrial cancer, however, have been few and inconsistent. ${ }^{11-13}$

Given the dual effects of phytoestrogen, high intake of soya foods may reduce the risk of endometrial cancer among women with high exposure to oestrogen but increase the risk or have no effect on risk among women with low oestrogen exposure. ${ }^{14} \mathrm{We}$ tested this hypothesis in a population based case-control study among Chinese women in Shanghai from 1997 to 2001.

\section{Methods}

Participants

Through the population based Shanghai Cancer Registry, we identified 982 women who were aged between 30 and 69 years and were given a diagnosis of endometrial cancer between January 1997 and December 2001. All these women were permanent residents of urban Shanghai. Interviews were completed for 832 $(84.7 \%)$ of them. Among the 150 non-participants, $73(7.4 \%)$ declined to be interviewed, $36(3.7 \%)$ had died, 22 (2.2\%) could not be located, $10(1.0 \%)$ were absent during the study period, and $9(0.9 \%)$ were ineligible for other reasons.

We randomly selected controls from the permanent female residents of the Shanghai urban area through the Shanghai Resident Registry and frequency matched them to cancer cases by age (five year intervals) at a ratio of 1:1. We determined the number of controls in each age specific stratum in advance according to the age distribution of the incident endometrial cancer cases in 1996. Women who had had a hysterectomy were not eligible $(n=36)$. Interviews were completed for 846 of the 1165 eligible controls, a response rate of $72.6 \%$. The reasons for non-participation were refusal $(n=277,23.8 \%)$ and absence during the study period $(\mathrm{n}=42,3.6 \%)$.

\section{Interviews and measurements}

Trained retired nurses conducted face to face interviews. The standardised, structured questionnaire used for the study covered demographic factors, menstrual and reproductive history, hormone use, usual dietary intake, disease history, tobacco and alcohol use, weight history, and family history of cancer. Information on exposure to these risk factors was collected for the period up to the reference date-that is, the date of diagnosis for cases and the date of interview for controls. Each participant was also measured for her current weight, circumferences of the waist and hip, and sitting and standing height. The median (25th to 75 th centile) interval between diagnosis and interview for cases was 5 (3 to 8) months. 
The interviewers collected information on usual dietary intake during the past five years by using a validated quantitative food frequency questionnaire. During the interview, each participant was first asked how often she ate a specific soya food or group of soya foods (per day, week, month, year, or never), followed by a question on how many liangs $(=50 \mathrm{~g})$ she ate of the particular food(s) per unit of time (day, week, month, or year) in the five years before the reference date. For seasonal foods (for example, fresh beans), study participants were asked to describe their consumption during the month(s) when the food was available. We estimated the average daily intakes for seasonal foods by calculating the percentage of months that a food was on the market over a one year period. We measured total intake of soya food according to intakes of soya protein and soya isoflavones. We estimated intake of soya protein by multiplying the amount of soya food consumed by the amount of protein in that food according to the Chinese food composition table. ${ }^{15}$ We calculated isoflavone intake by using published data on the isoflavone content of each soya food. ${ }^{16}$

We defined menopause as the cessation of menstrual periods before the reference date, excluding those lapses caused by pregnancy and nursing for at least 12 months. We calculated years of menstruation as age at reference date minus age at menarche for premenopausal women and age at menopause minus age at menarche for postmenopausal women, subtracting years with oral contraceptive use and years of pregnancy. We calculated body mass index $\left(\mathrm{g} / \mathrm{m}^{2}\right)$ and waist:hip circumference ratios by using measured anthropometric data.

\section{Statistical analysis}

We used unconditional logistic regression models to calculate odds ratios and their corresponding 95\% confidence intervals, in order to measure the association of endometrial cancer risk with soya food intake. We determined cut-off points for quarters of soya food consumption on the basis of intakes among control women. We tested for trend by entering the categorical variables as continuous parameters in the models, and we assessed interactions by stratified analyses and by including cross product terms in logistic models.

\section{Results}

Cases and controls were well matched on age distribution (table 1). No major differences between cases and controls existed with respect to marital status, family income, total energy intake, or use of hormone replacement therapy. However, compared with controls, cases attained higher education; had an earlier age at menarche, later age at menopause, and longer duration of menstruation; had higher body mass index and waist:hip ratio; and were less likely to take regular exercise, drink alcohol, or use oral contraceptives. Cases were also more likely to have a family history of cancer, have been pregnant fewer times, and have consumed more meat and fish. No significant differences existed between cases and controls for fruit and vegetable intake. We adjusted all subsequent analyses for age, energy intake, and the above mentioned significant variables as potential confounders.

Table 2 shows the case-control comparisons for consumption of total soya foods, soya protein, and soya isoflavones. Women with endometrial cancer had a lower intake of total soya foods and almost every individual soya food investigated, as well as total soya protein and soya isoflavones, than did controls, although most differences did not reach statistical significance. The median intake of soya protein and isoflavones was $9.9 \mathrm{~g} /$ day and $40.5 \mathrm{mg}$ /day for cases and $10.2 \mathrm{~g} /$ day and $42.5 \mathrm{mg}$ /day for
Table 1 Demographic characteristics and selected risk factors for endometrial cancer. Values are numbers (percentages) unless stated otherwise

\begin{tabular}{|c|c|c|c|}
\hline Characteristic & Cases $(n=832)$ & Controls $(n=846)$ & $P$ value \\
\hline Mean (SD) age (years) & $55.3(8.60)$ & $55.7(8.58)$ & 0.30 \\
\hline \multicolumn{4}{|l|}{ Education: } \\
\hline $\begin{array}{l}\text { No formal education or } \\
\text { just elementary school }\end{array}$ & $204(24.5)$ & $234(27.7)$ & \multirow[t]{3}{*}{0.08} \\
\hline Middle school & $503(60.5)$ & $513(60.6)$ & \\
\hline College and above & $125(15.0)$ & 99 (11.7) & \\
\hline \multicolumn{4}{|l|}{ Marital status: } \\
\hline Unmarried & $14(1.7)$ & $10(1.2)$ & \multirow[t]{3}{*}{0.68} \\
\hline Married or cohabiting & $724(87.0)$ & $742(87.7)$ & \\
\hline $\begin{array}{l}\text { Separated, divorced, or } \\
\text { widowed }\end{array}$ & $94(11.3)$ & $94(11.1)$ & \\
\hline \multicolumn{4}{|c|}{ Per capita income in previous year (yuan): } \\
\hline$\leq 4166.7$ & $230(27.7)$ & $244(28.9)$ & \multirow[t]{4}{*}{0.83} \\
\hline $4166.8-6250.3$ & $243(29.2)$ & $242(28.6)$ & \\
\hline $6250.4-8333.3$ & $57(6.9)$ & $50(5.9)$ & \\
\hline$\geq 8333.3$ & $301(36.2)$ & $309(36.6)$ & \\
\hline \multicolumn{4}{|l|}{ No of pregnancies: } \\
\hline None & $62(7.5)$ & $35(4.1)$ & \multirow[t]{6}{*}{$<0.01$} \\
\hline 1 & $137(16.5)$ & $109(12.9)$ & \\
\hline 2 & $199(23.9)$ & $208(24.6)$ & \\
\hline 3 & $194(23.3)$ & $207(24.5)$ & \\
\hline 4 & $141(17.0)$ & $157(18.6)$ & \\
\hline$\geq 5$ & $99(11.9)$ & $130(15.4)$ & \\
\hline $\begin{array}{l}\text { Cancer among first degree } \\
\text { relatives }\end{array}$ & $289(34.7)$ & $228(27.0)$ & $<0.01$ \\
\hline Postmenopausal (natural) & $492(59.1)$ & $541(64.0)$ & 0.03 \\
\hline Regular alcohol consumption & $20(2.4)$ & $42(5.0)$ & $<0.01$ \\
\hline Hormone replace therapy & $35(4.2)$ & $34(4.0)$ & 0.85 \\
\hline Oral contraceptive use & $147(17.7)$ & $207(24.5)$ & $<0.01$ \\
\hline Regular exercise & $253(30.4)$ & $287(33.9)$ & 0.12 \\
\hline Age at menarche ${ }^{*}$ & 14 (13 to 16$)$ & 15 (13 to 16$)$ & $<0.0001$ \\
\hline $\begin{array}{l}\text { Age at menopause (among } \\
\text { postmenopausal women) }{ }^{*}\end{array}$ & 50.1 (48.6 to 52.5$)$ & 49.4 (47.1 to 51.1$)$ & $<0.0001$ \\
\hline Years of menstruation ${ }^{\star}$ & 33.2 (30.0 to 36.1) & 31.5 (27.8 to 34.5$)$ & $<0.0001$ \\
\hline Body mass index* & 25.1 (22.7 to 27.9) & 23.7 (21.4 to 26.3 ) & $<0.0001$ \\
\hline $\begin{array}{l}\text { Waist:hip circumference } \\
\text { ratio* }^{*}\end{array}$ & 0.84 (0.81 to 0.87$)$ & 0.82 (0.78 to 0.85$)$ & $<0.0001$ \\
\hline $\begin{array}{l}\text { Usual energy intake } \\
(\mathrm{kcal} / \mathrm{day})^{*}\end{array}$ & $\begin{array}{c}2171.2 \\
(1871.4 \text { to } 2497.0)\end{array}$ & $\begin{array}{c}2141.5 \\
(1840.8 \text { to } 2485.2)\end{array}$ & 0.71 \\
\hline $\begin{array}{l}\text { Total fruit and vegetable } \\
\text { intake }(\mathrm{g} / \mathrm{day})^{*}\end{array}$ & 482.2 (330.6 to 671.8 ) & 477.0 (334.1 to 663.7) & 0.54 \\
\hline $\begin{array}{l}\text { Total meat and fish intake } \\
(\mathrm{g} / \mathrm{day})^{*}\end{array}$ & 115.2 (74.7 to 173.7$)$ & 102.0 (63.7 to 154.2) & $<0.01$ \\
\hline
\end{tabular}
$(\mathrm{g} / \text { day })^{\star}$

Participants with missing values excluded from analysis.

${ }^{*}$ Median (25th to 75th centile) presented.

controls. The average intake of soya food among control women was comparable to that in our previous study. ${ }^{17}$

As shown in table 3, after adjustment for dietary and non-dietary risk factors, the odds ratios for endometrial cancer associated with the highest quarter of intake of soya protein, soya fibre, soya isoflavones, and fresh soya bean intake were $0.67(95 \%$ confidence interval 0.48 to 0.92$), 0.69$ (0.51 to 0.94$), 0.77$ (0.56 to 1.05 ), and 0.63 (0.46 to 0.84 ), compared with the lowest quarter of intake. We also observed a dose-response relation for total intake of soya protein $(\mathrm{P}=0.01)$, soya fibre $(\mathrm{P}=0.02)$, and fresh soya beans $(\mathrm{P}=0.01)$. Additional adjustment for total fruit and vegetable intake did not alter the association (data not shown). Intakes of soya protein, soya fibre, and soya isoflavones were highly correlated, making it difficult to separate their independent effects.

Table 4 summarises the results of the stratified analysis by menopausal status (premenopausal, postmenopausal), body mass index $(<25, \geq 25)$, and waist:hip ratio $(\leq 0.855,>0.855)$. 
Table 2 Intake of soya food and soya protein among participants in the Shanghai endometrial cancer study. Values are medians (25th to 75th centiles) unless stated otherwise

\begin{tabular}{lccc} 
Food & Cases & Controls & P value $^{*}$ \\
\hline Soya food (g/day): & $106.5(54.4$ to 224.8$)$ & $116.3(55.4$ to 243.5$)$ & 0.08 \\
\hline Soya milk & $8.2(0.0$ to 107.1$)$ & $16.4(0$ to 107.1$)$ & 0.25 \\
\hline Tofu & $28.6(14.3$ to 57.1$)$ & $28.6(13.1$ to 57.1$)$ & 0.38 \\
\hline $\begin{array}{l}\text { Other processed soy } \\
\text { products }\end{array}$ & $16.4(8.2$ to 35.7$)$ & $16.4(7.1$ to 35.7$)$ & 0.77 \\
\hline Dry soya bean seeds & $0(0$ to 0.7$)$ & $0(0$ to 0.7$)$ & 0.38 \\
\hline Fresh soya beans & $6.3(2.2$ to 13.3$)$ & $6.3(2.8$ to 14.2$)$ & 0.13 \\
\hline Soya bean sprouts & $1.4(0$ to 4.9$)$ & $1.4(0$ to 6.6$)$ & 0.12 \\
\hline Soya protein $(\mathrm{g} /$ day $)$ & $9.9(5.9$ to 15.0$)$ & $10.2(5.9$ to 16.0$)$ & 0.26 \\
\hline Isoflavones $(\mathrm{mg} /$ day) & $40.5(22.7$ to 61.9$)$ & $42.5(22.6$ to 63.5$)$ & 0.13 \\
\hline${ }^{*} t$ test for geometric means. & & &
\end{tabular}

Although high soya food intake was related to a lower risk of endometrial cancer in all strata, the inverse association between intake of soya protein and risk of endometrial cancer was more pronounced among women with a higher body mass index $(\mathrm{P}$ for trend 0.01 ) or a higher waist:hip ratio (P for trend 0.01 ). We observed no multiplicative interactions. The association of soya intake with endometrial cancer did not vary by menopausal status, whether users of hormone replacement therapy (35 cases and 34 controls) were included in or excluded from the analysis.

\section{Discussion}

Incident rates of endometrial cancer vary more than 10 -fold worldwide ${ }^{18}$ In addition to host susceptibility, dietary factors may play an important role in this international variation. Asian countries have a low incidence of endometrial cancer and a high consumption of soya food. In our study population, the average intake of isoflavones from soya food was about 25 times that reported in a Western population $(42.5 \mathrm{mg} /$ day $v 1.7 \mathrm{mg} /$ day for controls), ${ }^{13}$ whereas the incident rate of endometrial cancer is only one fifth to one third that in Western countries. ${ }^{18}$

Soya isoflavones may play a role in the development of hormone related cancers, including endometrial cancer. ${ }^{19}$ Phytoestrogens have been shown to alter circulating concentrations of ovarian steroid hormones, prolong the menstrual cycle, alleviate symptoms of menopause, and enhance alkaline phosphatase activity in a human endometrial adenocarcinoma cell line, although evidence is not entirely consistent. ${ }^{19-21}$ An inverse association between phytoestrogen consumption and risk of endometrial cancer was reported by Goodman in a multiethnic population and by Horn-Ross among Western women. ${ }^{12}{ }^{13}$ However, legume intake was found to be associated with a slightly increased risk of endometrial cancer in an earlier study that we conducted among Chinese women. ${ }^{11}$ Some of these previous studies were not specifically designed to investigate the role of soya food, and the assessment of soya food intake was incomplete and sometimes mixed with other peas and beans. ${ }^{11} 12$ The sample sizes of the previous studies were relatively small, which limited the statistical power to evaluate the effect of soya food intake by menopausal status and body size.

This population based case-control study, specifically designed to test the hypothesis that soya food intake reduces endometrial cancer risk depending on endogenous hormone levels, indicates that usual consumption of soya foods by adults, measured as intake of either soya protein or soya isoflavones, is associated with a significantly reduced risk of endometrial cancer, particularly among women with a higher body mass index or waist:hip ratio. Although not all associations were statis-
Table 3 Association of endometrial cancer with soya food intake

\begin{tabular}{|c|c|c|c|}
\hline & Cases/controls & $\begin{array}{l}\text { Odds ratio } 1^{*} \\
(95 \% \mathrm{Cl})\end{array}$ & $\begin{array}{c}\text { Odds ratio } 2 \dagger \\
(95 \% \mathrm{Cl})\end{array}$ \\
\hline \multicolumn{4}{|c|}{ Isoflavones (mg/day) } \\
\hline$\leq 22.7$ & $207 / 212$ & 1.00 & 1.00 \\
\hline $22.8-42.5$ & $226 / 211$ & 1.10 (0.84 to 1.44$)$ & 0.98 (0.73 to 1.30$)$ \\
\hline $42.6-63.6$ & $203 / 212$ & 0.98 (0.75 to 1.29$)$ & 0.79 (0.59 to 1.07$)$ \\
\hline$>63.6$ & $196 / 211$ & 0.96 (0.73 to 1.26$)$ & 0.77 (0.56 to 1.05$)$ \\
\hline $\mathrm{P}$ for trend & & 0.58 & 0.05 \\
\hline \multicolumn{4}{|c|}{ Soya food fibre (g/day) } \\
\hline$\overline{\leq 0.4}$ & $212 / 212$ & 1.00 & 1.00 \\
\hline $0.5-0.8$ & $216 / 211$ & $1.03(0.78$ to 1.34$)$ & 0.91 (0.68 to 1.22$)$ \\
\hline $0.9-2.0$ & $225 / 212$ & $1.06(0.82$ to 1.39$)$ & 0.85 (0.63 to 1.13$)$ \\
\hline$>2.0$ & $179 / 211$ & 0.86 (0.65 to 1.13$)$ & 0.69 (0.51 to 0.94$)$ \\
\hline $\mathrm{P}$ for trend & & 0.36 & 0.02 \\
\hline \multicolumn{4}{|c|}{ Soya protein (g/day) } \\
\hline$\overline{\leq 5.9}$ & $209 / 212$ & 1.00 & 1.00 \\
\hline $6.0-10.2$ & $220 / 211$ & 1.06 (0.81 to 1.39$)$ & 0.93 (0.69 to 1.24$)$ \\
\hline $10.3-16.0$ & $222 / 212$ & 1.07 (0.82 to 1.39$)$ & 0.85 (0.63 to 1.14$)$ \\
\hline$>16.0$ & $181 / 211$ & 0.88 (0.66 to 1.15$)$ & 0.67 (0.48 to 0.92$)$ \\
\hline $\mathrm{P}$ for trend & & 0.40 & 0.01 \\
\hline
\end{tabular}

Specific soya food intake (g/day)

Soya milk:

\begin{tabular}{llll}
\hline Never & $400 / 391$ & 1.00 & 1.00 \\
\hline$\leq 1.9$ & $184 / 195$ & $0.92(0.72$ to 1.18$)$ & $0.90(0.70$ to 1.17$)$ \\
\hline
\end{tabular}

\begin{tabular}{lccc}
$\leq 1.9$ & $184 / 195$ & $0.92(0.72$ to 1.18$)$ & $0.90(0.70$ to 1.17$)$ \\
\hline$>1.9$ & $248 / 260$ & $0.93(0.75$ to 1.17$)$ & $0.86(0.68$ to 1.10$)$ \\
\hline$P$ for trend
\end{tabular}

\begin{tabular}{|c|c|c|}
\hline $\mathrm{P}$ for trend & 0.52 & 0.22 \\
\hline Tofu: & & \\
\hline
\end{tabular}

\begin{tabular}{lllr}
\hline$\leq 0.8$ & $205 / 218$ & 1.00 & \multicolumn{2}{c}{1.00} \\
\hline $0.9-1.8$ & $322 / 299$ & $1.15(0.89$ to 1.47$)$ & $110 \quad(0.85$ to 1.44$)$ \\
\hline $1.9-3.5$ & $227 / 237$ & $1.02(0.78$ to 1.33$)$ & $0.90(0.68$ to 1.21$)$ \\
\hline
\end{tabular}

\begin{tabular}{lccc}
\hline $1.9-3.5$ & $227 / 237$ & $1.02(0.78$ to 1.33$)$ & $0.90(0.68$ to 1.21$)$ \\
\hline$>3.5$ & $78 / 92$ & $0.90(0.63$ to 1.29$)$ & $0.80(0.54$ to 1.19$)$ \\
\hline
\end{tabular}

\begin{tabular}{lcc}
$>$ & $78 / 92$ & $0.50(0.63$ frend \\
\hline
\end{tabular}

Processed soya products, excluding tofu:

\begin{tabular}{llll}
\hline$\leq 1.8$ & $198 / 213$ & 1.00 & 1.00 \\
\hline $1.9-5.3$ & $225 / 211$ & $1.15(0.88$ to 1.51$)$ & $1.07(0.81$ to 1.43$)$ \\
\hline $5.4-8.8$ & $301 / 309$ & $1.04(0.81$ to 1.34$)$ & $0.90(0.68$ to 1.18$)$ \\
\hline$>8.8$ & $108 / 113$ & $1.03(0.74$ to 1.43$)$ & $0.84(0.59$ to 1.21$)$ \\
\hline
\end{tabular}

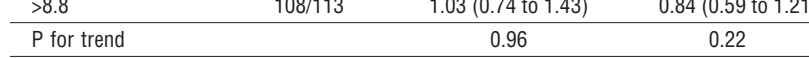

Dry soya bean seeds:

\begin{tabular}{llll}
\hline Never & $485 / 518$ & 1.00 & 1.00 \\
\hline$\leq 0.5$ & $171 / 130$ & $1.40(1.08$ to 1.82$)$ & $1.48(1.12$ to 1.95$)$ \\
\hline$>0.5$ & $176 / 198$ & $0.96(0.75$ to 1.21$)$ & $0.94(0.73$ to 1.21$)$
\end{tabular}

\begin{tabular}{lccc}
\hline$>0.5$ & $176 / 198$ & $0.96(0.75$ to 1.21$)$ & $0.94(0.73$ to 1.21$)$ \\
\hline $\mathrm{P}$ for trend & 0.82 & 0.84
\end{tabular}

\begin{tabular}{lll} 
Fresh soya beans: & 0.82 & 0.84 \\
\hline
\end{tabular}

\begin{tabular}{llll}
\hline$\leq 0.4$ & $246 / 213$ & 1.00 & 1.00 \\
\hline $0.5-0.8$ & $206 / 242$ & $0.73(0.56$ to 0.95$)$ & $0.65(0.49$ to 0.85$)$ \\
\hline $0.9-1.9$ & $194 / 182$ & $0.92(0.70$ to 1.21$)$ & $0.81(0.61$ to 1.09$)$
\end{tabular}

\begin{tabular}{llll}
\hline $0.9-1.9$ & $194 / 182$ & $0.92(0.70$ to 1.21$)$ & $0.81(0.61$ to 1.09$)$ \\
\hline$>1.9$ & $186 / 209$ & $0.78(0.59$ to 1.02$)$ & $0.63(0.46$ to 0.84$)$
\end{tabular}

$\begin{array}{ccc}P \text { for trend } & 0.20 & 0.01\end{array}$

\begin{tabular}{llll}
\hline Soya bean sprouts: & & & \\
\hline Never & $322 / 319$ & 1.00 & 1.00 \\
\hline$\leq 0.2$ & $238 / 226$ & $1.05(0.82$ to 1.33$)$ & $1.10(0.85$ to 1.42$)$ \\
\hline$>0.2$ & $272 / 301$ & $0.89(0.71$ to 1.11$)$ & $0.89(0.70$ to 1.14$)$ \\
\hline
\end{tabular}

\begin{tabular}{|c|c|c|c|}
\hline$>0.2$ & $2 / 2+2+3$ & 0.89 (0.11 to 1.11$)$ & 0.89 (0.10 to 1.14$)$ \\
\hline $\mathrm{P}$ for trend & & 0.31 & 030 \\
\hline
\end{tabular}

\section{${ }^{*}$ Adjusted for age}

†Adjusted for age, education, menopausal status, years of menstruation, first degree family history of any cancer, oral contraceptive use, physical activity, number of pregnancies, body mass index, total meat intake, and energy intake.

tically significant in subgroup analyses, the different measurements produced similar results.

Menopausal status, body mass index, and waist:hip ratio are associated with endogenous concentrations of sex hormones. ${ }^{22} 23$ Our finding of a more pronounced inverse association between soya food intake and risk of endometrial cancer among women with a higher body mass index or waist:hip ratio ( $\mathrm{P}$ for trend $<0.05)$ are in line with our study hypothesis that soya food 
Table 4 Association of endometrial cancer with soya protein intake by body mass index, waist:hip ratio, and menopausal status. ${ }^{*}$ Values are odds ratios (95\% confidence intervals) unless stated otherwise

\begin{tabular}{|c|c|c|c|c|c|c|}
\hline \multirow[b]{2}{*}{ Stratifying variables } & \multirow[b]{2}{*}{ No of cases/controls } & \multicolumn{4}{|c|}{ Soya protein intake by quarter (g/week) } & \multirow[b]{2}{*}{$P$ for trend } \\
\hline & & Q1 & Q2 & Q3 & Q4 & \\
\hline \multicolumn{7}{|l|}{ Body mass indext: } \\
\hline$<25$ & $406 / 532$ & 1.00 & $0.91(0.62$ to 1.35$)$ & $0.96(0.65$ to 1.41$)$ & 0.79 (0.52 to 1.20$)$ & 0.34 \\
\hline$\geq 25$ & $418 / 312$ & 1.00 & 0.87 (0.56 to 1.33$)$ & 0.77 (0.49 to 1.19$)$ & 0.51 (0.31 to 0.84$)$ & 0.01 \\
\hline $\begin{array}{l}\text { Test for multiplicative } \\
\text { interaction }\end{array}$ & & & & $P=0.12$ & & \\
\hline \multicolumn{7}{|c|}{ Waist:hip ratio (by 75th centile)‡: } \\
\hline$\leq 0.855$ & $508 / 633$ & 1.00 & $1.03(0.73$ to 1.46$)$ & 0.81 (0.56 to 1.16$)$ & 0.80 (0.55 to 1.18$)$ & 0.13 \\
\hline$>0.855$ & $321 / 212$ & 1.00 & $0.95(0.55$ to 1.62$)$ & $0.95(0.55$ to 1.66$)$ & $0.39(0.21$ to 0.74$)$ & 0.01 \\
\hline $\begin{array}{l}\text { Test for multiplicative } \\
\text { interaction }\end{array}$ & & & & $P=0.22$ & & \\
\hline \multicolumn{7}{|l|}{ Menopausal status§: } \\
\hline Premenopausal & $315 / 295$ & 1.00 & $0.90(0.56$ to 1.46$)$ & $0.69(0.42$ to 1.14$)$ & $0.71(0.42$ to 1.19$)$ & 0.12 \\
\hline Postmenopausal & $470 / 512$ & 1.00 & $0.95(0.65$ to 1.40$)$ & $0.88(0.60$ to 1.31$)$ & 0.71 (0.46 to 1.09$)$ & 0.12 \\
\hline $\begin{array}{l}\text { Test for multiplicative } \\
\text { interaction }\end{array}$ & & & & $\mathrm{P}=0.92$ & & \\
\hline
\end{tabular}

${ }^{*}$ Adjusted for age, education, years of menstruation, first degree family history of any cancer, oral contraceptive use, number of pregnancies, physical activity, total meat and fish intake, and total energy intake.

†Additionally adjusted for menopausal status.

†Additionally adjusted for menopausal status and body mass index.

§Additionally adjusted for body mass index. Eighteen women with induced menopause and 79 users of hormone replacement therapy were excluded from this analysis.

exerts an antioestrogenic effect in an oestrogen rich environment. However, the finding of a similar inverse association among premenopausal and postmenopausal women did not seem to support the above mentioned hypothesis or the findings from a recent US study that suggested a stronger effect of soya on endometrial cancer among postmenopausal women. ${ }^{13}$ Studies with measured oestrogen concentrations are needed to better understand the joint effect of soya and endogenous oestrogen on endometrial cancer risk.

\section{Strengths and weaknesses}

Our study has many strengths. Soya consumption is high and constant among Chinese people, making this population an ideal setting in which to evaluate the effect of soya. The food frequency questionnaire used in this study, which covers about $86 \%$ of common foods consumed by Shanghai residents and includes 17 soya foods or soya food groups, has been validated with a correlation of 0.49 for assessment of soya intake derived from the questionnaire and from 24 hour recalls. ${ }^{24}$ The correlation of soya intake assessed by two food frequency questionnaires administered approximately two years apart was $0.37 .^{24}$ The population based design, high response rate, and low frequency of hysterectomy in the study population minimised selection bias. Potential confounding from dietary and non-dietary risk factors was adjusted for in the analysis. The low frequency of use of hormone replacement therapy has exempted our study from the influence of this important potential confounder. However, it also limited our ability to investigate the effect of soya among women who have high oestrogen concentrations from an exogenous source.

As with all case-control studies, potential recall bias and measurement error are of concern. Non-differential misclassification in dietary assessment would bias the results towards null. Change of dietary practice after diagnosis of disease, however, would bias the risk estimate either towards or away from null. Although we specifically asked study participants to report their usual dietary intake during the five years before the diagnosis date for cases and the interview date for controls, ignoring recent dietary changes, the recall of dietary intake could still have been influenced by recent dietary practice. In the study, $17.9 \%$ of cases and $7.6 \%$ of controls reported an increased intake of soya food during the seven days before the interview, $8.8 \%$ of cases and $10.0 \%$ of controls reported a decrease, and $73.4 \%$ of cases and $82.4 \%$ of controls reported no change. Analysis restricted to women who reported no recent dietary change resulted in a slightly stronger inverse association between intake of soya food and risk of endometrial cancer (data not shown), suggesting that the effect of soya food on endometrial cancer is probably underestimated in this study.

\section{Conclusions}

This study found an inverse dose-response relation between intake of soya food and the risk of endometrial cancer. The indication that women with a high body mass index or waist:hip ratio may benefit more from increased soya food intake needs to be verified in future studies.

We thank Fan Jin for her contributions in implementing the study in Shanghai and Bethanie Hull for technical assistance in the preparation of this manuscript. This study would not have been possible without the support of all of the study participants and research staff of the Shanghai endometrial cancer study.

Contributors: All authors contributed to analysis and preparation of the manuscript. ZXR directed field operations, and JRC directed the laboratory work. XOS was the principal investigator, responsible for designing and directing implementation of the overall study, and is the guarantor of this paper.

Funding: This work was funded by United States Public Health Service (USPHS) grant number R01CA92585 from the National Cancer Institute.

\section{What is already known on this topic}

Endogenous oestrogens have a central role in the aetiology of endometrial cancer

Soya foods are a rich source of isoflavones, a major group of phytoestrogens that have both weak oestrogenic and antioestrogenic activities, depending on dose and tissue

\section{What this study adds}

Regular intake of soya foods is associated with a reduced risk of endometrial cancer, particularly among overweight women 
Competing interests: None declared.

Ethical approval: This study was approved by the institutional review boards of Vanderbilt University and the Shanghai Cancer Institute.

1 Alelson M, Setchell KDR, Gustafsson BE. Soya-a dietary source of the non-steroida estrogen equol in man and animals. J Endocrinol 1983;102:49-56.

2 Kelly GE, Joannou GE, Reeder AY, Nelson C, Waring MA. The variable metabolic response to dietary isoflavones in humans. Proc Soc Exp Biol Med 1995;208:40-3.

3 Messina MJ, Persky V, Setchell KD, Barnes S. Soy intake and cancer risk: a review of the in vitro and in vivo data. Nutr Cancer 1994;21;113-31.

4 Adlercreutz H, Mazur W. Phyto-oestrogens and Western disease. Ann Med 1997;29:95120.

5 Adlercreutz H. Phyto-estrogens: epidemiology and a possible role in cancer protection. Environ Health Perspect 1995;103:103-12.

6 Adlercreutz H, Honjo H, Higashi A. Urinary excretion of lignans and isoflavonoid phytoestrogens in Japanese men and women consuming a traditional Japanese diet. Am J Clin Nutr 1991;54:93-100.

7 Rose DP. Dietary fiber and breast cancer. Nutr Cancer 1990;13:1-8.

8 Goldin BR, Adlercreutz H, Gorbach SL, Warram JH, Dwyer JT, Swenson L, et al. Estrogen excretion patterns and plasma levels in vegetarian and omnivorous women. $N$ Engl gen excretion pattern

9 Henderson BE, Ross RK, Pike MC, Casagrande JT. Endogenous hormones as a major actor in human cancer. Cancer Res 1982;42:3232-9.

10 Kaku T, Silverberg SG, Tsukamoto N, Tsuruchi N, Kamura T, Saito T, et al. Association of endometrial epithelial metaplasias with endometrial carcinoma and hyperplasia in Japanese and American women. Int J Gynecol Pathol 1993;12:297-300.

11 Shu XO, Zheng W, Potischman N, Brinton LA, Hatch MC, Gao YT, et al. A populationbased case-control study of dietary factors and endometrial cancer in Shanghai, People's Republic of China. Am J Epidemiol 1993;137:155-65.

12 Goodman MT, Wilkens LR, Hankin JH, Lyu LC, Wu AH, Kolonel LN. Association of soy and fiber consumption with the risk of endometrial cancer. Am J Epidemiol 1997;146:294-306.

13 Horn-Ross PL, John EM, Canchola AJ, Stewart SL, Lee MM. Phytoestrogen intake and endometrial cancer risk. J Natl Cancer Inst 2003;95:1158-64.

14 Hale GE, Hughes CL, Cline JM. Endometrial cancer: hormonal factors, the perimenopausal "window of risk", and isoflavones. J Clin Endocrinol Metab 2002;87:3-15.

15 Chinese Academy of Medical Sciences. Food composition tables. Beijing: People's Health Publishing House, 1991

16 Chen Z, Zheng W, Custer LJ, Dai Q, Shu XO, Jin F, et al. Usual dietary consumption of soy foods and its correlation with the excretion rate of isoflavonoids in overnight urine samples among Chinese women in Shanghai. Nutr Cancer 1999;33:2-87.
17 Dai $\mathrm{O}$ Shu XO, Jin F, Potter JD, Kushi LH, Teas J, et al. Population-based case-control study of soyfood intake and breast cancer risk in Shanghai. Br J Cancer 2001;85:372-8. 18 Parkin DM, Whelan SL, Ferlay J, Raymond L, Young J. Cancer incidence in five continents. Vol VII, No 143. IARC Scientific Publications, 1997.

19 Burton JL, Wells M. The effects of phytoestrogen on the female genital tract. J Clin Pathol 2002;55:401-7.

20 Markiewicz L, Garey J, Aldercreutz H, Gurpide E. In vitro bioassays of non-steroidal phytoestrogens.J Steroid Biochem Mol Biol 1993;45:399-405.

21 Kumar NB, Cantor A, Allen K, Riccardi D, Cox CE. The specific role of isoflavones on estrogen metabolism in premenopausal women. Cancer 2002;94:1166-74.

22 Potischman N, Hoover RN, Brinton LA, Siiteri P, Dorgan JF, Swanson CA, et al. Casecontrol study of endogenous steroid hormones and endometrial cancer. J Natl Cancer Inst 1996;88:1127-35.

23 Potischman N, Swanson CA, Siiteri P, Hoover RN. Reversal of relation between body mass and endogenous estrogen concentrations with menopausal status. J Natl Cancer Inst 1996;88:756-8.

24 Shu XO, Yang G, Jin F, Kushi L, Liu D, Wen W, et al. Validity and reproducibility of food frequency questionnaire used in the Shanghai women's health study. Eur J Clin Nutr 2004;58:17-23.

(Accepted 18 March 2004)

doi 10.1136/bmj.38093.646215.AE

Department of Epidemiology, Shanghai Cancer Institute, 2200 Xie Tu Road \#25, Shanghai 200032, China

Wang Hong Xu assistant professor

Yong Bing Xiang professor

Zhi Xian Ruan research staff

Jia Rong Cheng research staff

Yu Tang Gao professor

Department of Medicine, Vanderbilt-Ingram Cancer Center, Vanderbilt Center for Health Services Research, Vanderbilt University, 6009 Medical Center East, 1215 21st Avenue South, Nashville, TN 37232-8300, USA

Wei Zheng professor

Qi Dai assistant professor

Xiao Ou Shu professor

Correspondence to: X O Shu Xiao-Ou.Shu@vanderbilt.edu 